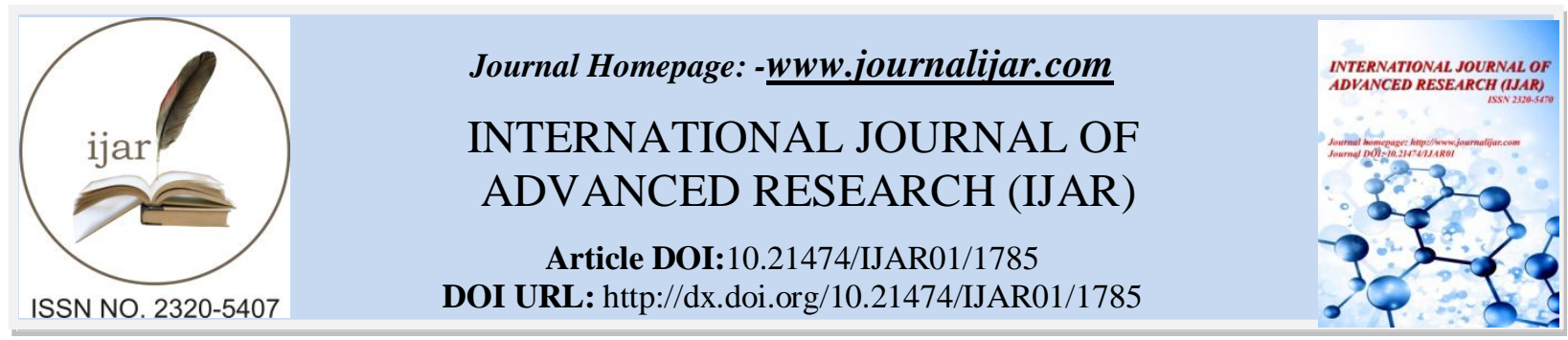

RESEARCH ARTICLE

\title{
NEW CONDENSED BIOACTIVE PYRIMIDINES. SYNTHETIC STRATEGIES, STRUCTURAL CHARACTERIZATION AND BIORATIONAL STUDIES.
}

\author{
Abdelmonim El-Torgoman ${ }^{1}$, Sherif M. Sherif ${ }^{2}$, Mamdouh I. Nassar ${ }^{3}$, Hatem M. Gaber ${ }^{4}$ and Doaa A. Zaki ${ }^{1}$. \\ 1. Department of Chemistry, Faculty of Science, Menoufia University, Shibin Al kawm, Egypt. \\ 2. Department of Chemistry, Faculty of Science, Cairo University, Giza 12613, Egypt. \\ 3. Department of Entomology, Faculty of Science, Cairo University, Giza 12613, Egypt. \\ 4. National Organization for Drug Control and Research (NODCAR), P.O. Box 29, Cairo, Egypt.
}

\section{Manuscript Info}

-........................

Manuscript History

Received: 12 August 2016

Final Accepted: 22 September 2016

Published: October 2016

Key words:-

Pyrimidine Formylation Hydrolysis

Alkylation Cyclodehydration,

Biologicalactivity, Toxicology and

Culexpipiens.

\section{Abstract}

Versatile 3-aminopyrrolopyridine-2-carboxylate and -2-carboxylic acid derivatives 2a,bwere obtained based on an orthofunctionalized pyrrole derivative $\mathbf{1}$. Initially cyclization of ester 2a followed by formylation to obtain a tricyclic chloroaldehyde derivative $\mathbf{4}$, which on further treatment with hydroxylamine hydrochloride yielded the corresponding oxime5a. The latter product was subsequently dehydrated forming the tricyclic 2-cyanopyrimidine derivative $\mathbf{5 b}$. Other different 2-functionalized tricyclic derivatives of $\mathrm{N}-3$ substituted pyrimidine were synthesized, for biorational assessment, starting from the key precursors $\mathbf{2 a}, \mathbf{b}$ through convenient methods. All condensed tricyclic pyrimidine derivatives with the common 7,9diphenyl-8-(4-methoxyphenylazo) substitution patternwere evaluated for their toxicity on the $4^{\text {th }}$ larval instar of the mosquitoes, Culexpipiens. The compounds under investigation displayed different levels of biorational effects. In general, chloro compounds 4, 5a and 5b that have a chlorine atom as a substituent on the C-4 atom of the pyrimidine ring, showed high insecticidal activity, with compound $\mathbf{5 b}$ showing essentially the highest biorational effect. The lethal concentration at $\mathrm{LC}_{50}$ of the latter compound $\mathbf{5 b}$ is very significant $(0.22 \%)$. Our results may provide some guidance for development of some novel chloropyrimidine-based insecticidal lead structures. The detailed synthesis and biological screening data were reported.

Copy Right, IJAR, 2016,. All rights reserved.

\section{Introduction:-}

There has been an increasing demand for new bioactive agents, as the fast development of pests resistance to conventional chemicals is one of the major difficulties in the treatment. Researchers have been used new novel chemicals as bio-agents effects because they attended that the conventional chemicals have been adverse action on the non-target organisms.

In the course of reviewing various structures which may be of use in the design of novel bioactive and biorational agents, condensed pyrimidines have attracted much of our attention because of their synthetic and biological 
importance [1-4]. Many studies have been evaluated about the mode of action of different chemicals against pests as well as bacteria and other microorganisms. Mosquitoes are generally controlled by conventional chemical insecticides, but insect growth inhibitors and insect growth regulators, in general, have been employed in the laboratory against different species of mosquitoes. It has been reported [5] that the three chitin synthesis inhibitors (diflubenzuron, nikkomycin $\mathrm{Z}$ and polyoxin $\mathrm{D}$ ) produced toxicities against Anopheles quadrimaculatus. It is well documented[6] that increased resistance of malaria parasites to drug treatment against mosquito vectors to insecticides requires the development of novel chemotherapeutic agents.

In recent studies [7, 8], it has been described that benzoylphenyl urea derivatives such as Alsystin (Triflumuron) and Andalin (Flucycloxuron) were found to disturb the growth and development in Culexpipiens. On the other hand, Cassera et al. [6] mentioned that Plasmodium purine and pyrimidine metabolic pathways are distinct from those of their hosts. Thus, targeting purine and pyrimidine metabolic pathways provides a promising route for novel drug development [9].

Furthermore, the pyrazolo[4,3-e]1,2,4-triazolo[1,5-c]pyrimidine structure was characterized as a new class of potent and selective human $\mathrm{A}_{3}$ adenosine receptor antagonists [9]. High-affinity radioligand antagonist for this receptor subtype, designated as $\left[{ }^{3} \mathrm{H}\right] \mathrm{MRE} 2008 \mathrm{~F} 20$ [10]. Accordingly, an aquatic insect, the larva of the mosquito (CulexpipiensL.) was chosen for the purpose and proved to be an excellent for test.

Based on these observations and as part of our ongoing studies in the development of new chemotherapeutic agents $[11,12,13]$, we embarked upon the synthesis of a series of novel condensed tricyclic derivatives containing a pyrido[ $\left[3^{\prime}, 2^{\prime}: 4,5\right]$ pyrrolo[3,2-d]pyrimidine core with the objective to assess new biorational agents on mosquitoes Culexpipiensand to improve their efficacy.

\section{Materials and methods:- Chemistrymaterials:-}

Melting points are uncorrected. IR analyses were performed (KBr) with a PyeUnicam SP-1000 spectrophotometer. IR spectra of compounds are expressed by wavenumber $\left(\mathrm{cm}^{-1}\right)$. NMR spectra were obtained on a Varian Gemini 300 MHz spectrometer in DMSO- $d_{6}$ as solvent. Chemical shifts of the ${ }^{1} \mathrm{H}$ NMR spectra are reported in $\delta(\mathrm{ppm})$ from tetramethylsilane with the solvent as the $)$, anhydrous potassium carbonate $(0.01 \mathrm{~mol})$ and ethyl glycinate $(0.0075$ mol) were added. The reaction mixture was heated at reflux for $2.5 \mathrm{~h}$ and then allowed to stand at room temperature overnight under stirring. The reaction mixture was then diluted with cold water, whereby the resulting precipitate was collected by filtration, repeatedly washed with cold water and dried. Recrystallization from $\mathrm{DMF}-\mathrm{H}_{2} \mathrm{O}$ gave pale yellow crystals of the title compound 2 (0.68 g; 55\%), mp 193-194 C; IR (v/cm $\left.{ }^{-1}\right): 3312-3240(2 \mathrm{NH}), 3041$ (arom CH), 1677, $1672(2 \mathrm{CO}) ;{ }^{1} \mathrm{H}$ NMR $(\delta \mathrm{ppm}): 1.35$ (t, $3 \mathrm{H}, J=7.2 \mathrm{~Hz}$, ester Me), $4.46(\mathrm{q}, 2 \mathrm{H}, J=7.2 \mathrm{~Hz}$, ester $\left.\mathrm{CH}_{2}\right), 7.24-8.09(\mathrm{~m}, 15 \mathrm{H}, 3 \mathrm{PhH}), 9.58\left(\mathrm{~s}, 1 \mathrm{H}, \mathrm{NHCS}, \mathrm{D}_{2} \mathrm{O}\right.$-exchangeable), $11.20\left(\mathrm{~s}, \mathrm{br}, 1 \mathrm{H}, \mathrm{NHCO}, \mathrm{D}_{2} \mathrm{O}-\right.$ exchangeable); MS: $m / z(\%)=514\left(\mathrm{M}^{+}, 15 \%\right)$; Anal. Calcd. for $\mathrm{C}_{27} \mathrm{H}_{22} \mathrm{~N}_{4} \mathrm{O}_{3} \mathrm{~S}_{2}$ (514.619): $\mathrm{C}, 63.02 ; \mathrm{H}, 4.31 ; \mathrm{N}$, 10.89; S, 12.46. Found: C, 62.79; H, 4.20; N, 10.71; S, 12.21.

\section{Synthesis of 5-phenyl-6-phenylazo-2-thioxo-2,3-dihydrothieno[2,3-d]pyrimidin-4(1H)-one (3):- Method A:}

A mixture of compound $2(0.003 \mathrm{~mol})$ and potassium hydroxide $(0.008 \mathrm{~mol})$ in absolute ethanol $(20 \mathrm{~mL})$ was refluxed for $1 \mathrm{~h}$. After cooling, the precipitate was filtered off, dissolved in water and then acetic acid was added until precipitation was complete. The material which separated upon cooling was isolated by filtration as yellowish white crystals $(0.71 \mathrm{~g} ; 39 \%), \mathrm{mp} 171-172 \mathrm{C}$; IR $\left(\mathrm{v} / \mathrm{cm}^{-1}\right)$ : 3200, $3100(2 \mathrm{NH}), 3038$ (arom CH), 1670 (CO), 1194 $(\mathrm{CS}) ;{ }^{1} \mathrm{H}$ NMR $(\delta \mathrm{ppm}): 7.16-7.51(\mathrm{~m}, 10 \mathrm{H}, 2 \mathrm{PhH}), 12.67\left(\mathrm{~s}, 1 \mathrm{H}, \mathrm{CONH}, \mathrm{D}_{2} \mathrm{O}\right.$-exchangeable), $13.02(\mathrm{~s}, 1 \mathrm{H}, \mathrm{NH}$, $\mathrm{D}_{2} \mathrm{O}$-exchangeable); ${ }^{13} \mathrm{C}$ NMR $(\delta \mathrm{ppm})$ : $116.9(\mathrm{C}-4 \mathrm{a}), 127.0,127.5,127.9,128.3,128.6,129.4,132.3,135.2,142.1$, 152.5, 153.0, 159.7 (CO), 173.9 (CS); MS: $m / z(\%)=364\left(\mathrm{M}^{+}\right.$, 21\%); Anal. Calcd. for $\mathrm{C}_{18} \mathrm{H}_{12} \mathrm{~N}_{4} \mathrm{OS}_{2}$ (364.444): C, 59.32; H, 3.32; N, 15.37; S, 17.60. Found: C, 59.11; H, 3.18; N, 15.24; S, 17.38.

\section{Method B:}

To a solution of thioethyl derivative $\mathbf{1}(0.005 \mathrm{~mol})$ in dimethylformamide $(25 \mathrm{ml})$, anhydrous potassium carbonate $(0.01 \mathrm{~mol})$ and glycine $(0.0075 \mathrm{~mol})$ were added. The reaction mixture was heated at reflux for $2 \mathrm{~h}$ and then allowed to stand at room temperature overnight under stirring. The reaction mixture was then diluted with cold water, whereby the resulting precipitate was collected by filtration, dried and purified by recrystallization from $D M F-\mathrm{H}_{2} \mathrm{O}$ 
to give a solid product, in $55 \%$ yield, identical in every respect (mp, mixed $\mathrm{mp}$ and IR data) to that obtained above from method A.

Synthesis of 3-methyl-2-methylthio-5-phenyl-6-(phenylazo)thieno[2,3-d]pyrimidin-4(3H)-one (4):-

A solution of compound $2(0.002 \mathrm{~mol})$ and formamide $(20 \mathrm{ml})$ was refluxed for $4 \mathrm{~h}$. The reaction mixture was cooled and crude product was filtered off, washed with petroleum ether, dried and purified by recrystallization from dimethylformamide to give the tricyclic pyrimidinone derivative 4 as a pale yellow solid $(0.61 \mathrm{~g} ; 52 \%), \mathrm{mp} 193-194$ $\mathrm{C}$; IR $\left(\mathrm{v} / \mathrm{cm}^{-1}\right): 3058$ (arom CH), $1669(\mathrm{CO}) ;{ }^{1} \mathrm{H}$ NMR $(\delta \mathrm{ppm}): 2.56$ (s, 3H, SMe), 3.61 (s, 3H, NMe), 7.14-7.50 (m, $10 \mathrm{H}, 2 \mathrm{PhH}) ;{ }^{13} \mathrm{C}$ NMR $(\delta \mathrm{ppm}): 14.8(\mathrm{SMe}), 30.2(\mathrm{NMe}), 117.9,127.1,127.4,127.8,128.2,128.9,129.5,132.6$, 135.1, 142.3, 152.6, 156.7, 159.4 (C-2), 160.5 (CO); Anal. Calcd. for $\mathrm{C}_{20} \mathrm{H}_{16} \mathrm{~N}_{4} \mathrm{OS}_{2}(392.497)$ : C, 61.20; H, 4.11; N, 14.27; S, 16.34. Found: C, 60.95; H, 3.96; N, 14.10; S, 16.12.

Synthesis of ethyl 2-(2-methylthio-4-oxo-5-phenyl-6-(phenylazo)thieno[2,3-d]pyrimidin-3(4H)-yl)acetate (5):Vilsmeier-Haack reagent $(1 \mathrm{~mol}=300 \mathrm{~g})$ was prepared by adding dropwisephosphoryl chloride $(150 \mathrm{~g}, 1 \mathrm{~mol})$, in an ice-cold condition $\left(0-5^{\circ} \mathrm{C}\right)$ under constant stirring to dry dimethylformamide $(150 \mathrm{~g}, 2 \mathrm{~mol})$ over a period of $1 \mathrm{~h}$. After the addition was complete, stirring was continued for further $1 \mathrm{~h}$ at the same temperature $\left(0-5^{\circ} \mathrm{C}\right)$. Then, a solution of compound $5(0.0015 \mathrm{~mol})$ at least amount of dry dimethylformamide $(1 \mathrm{ml})$ was added in portions with stirring to two molar equivalent amount $(0.9 \mathrm{~g}, 0.003 \mathrm{~mol})$ of the above reagent $(1 \mathrm{~mol}=300 \mathrm{~g})$. The whole was allowed to attain room temperature under stirring. The reaction content was heated at reflux for $2 \mathrm{~h}$ and left aside overnight to cool. After cooling, the mixture was poured onto ice. To the clear solution was added carefully dilute aqueous sodium hydroxide solution under cooling until a $\mathrm{pH}$ value of 8-9 was reached. The precipitate was separated and purified by recrystallization from ethanol to give yellow crystals of the title compound $\mathbf{5}$ (0.68 g; 49\%), mp 193-194 C; IR ( $\left./ / \mathrm{cm}^{-1}\right): 3063$ (arom CH), 1730 (ester CO), 1677 (pyrimidine CO); ${ }^{1} \mathrm{H}$ NMR $(\delta$ ppm): 1.32 (t, 3H, $J=7.4 \mathrm{~Hz}$, ester Me), 2.63 (s, 3H, SMe), 4.10 (q, 2H, J = 7.4 Hz, ester $\mathrm{CH}_{2}$ ), 4.70 (s, 2H, NCH $\left.2 \mathrm{CO}\right), 7.17-$ 7.49 (m, 10H, 2PhH); Anal. Calcd. for $\mathrm{C}_{23} \mathrm{H}_{20} \mathrm{~N}_{4} \mathrm{O}_{3} \mathrm{~S}_{2}$ (464.560): C, 59.46; H, 4.34; N, 12.06; S, 13.80. Found: C, 59.26; H, 4.25; N, 11.87; S, 13.62.

Synthesis of 3,6-diphenyl-7-phenylazo-5H-thiazolo[3,2-a]thieno[2,3-d]pyrimidin-5-one (6a):-

To $15 \mathrm{ml}$ of glacial acetic acid was added compound $4(0.001 \mathrm{~mol}), 1 \mathrm{ml}$ of water and hydroxylamine hydrochloride $(0.7 \mathrm{~g}, 0.01 \mathrm{~mol})$. The reaction mixture was warmed for a few minutes under stirring, then diluted with water to the precipitation point and cooled in ice. The crystalline product, which was deposited, recrystallized from petroleum ether affording the title compound $6 \mathbf{a}$ as a dark brown solid $(0.75 \mathrm{~g} ; 54 \%), \mathrm{mp} 219-221 \mathrm{C} ; \mathrm{IR}\left(\mathrm{v} / \mathrm{cm}^{-1}\right): 3060(\mathrm{arom}$ $\mathrm{CH}), 1704(\mathrm{CO}) ;{ }^{1} \mathrm{H} \mathrm{NMR}(\delta \mathrm{ppm}): 6.97(\mathrm{~s}, 1 \mathrm{H}$, thiazole $\mathrm{H}-2), 7.20-7.63(\mathrm{~m}, 15 \mathrm{H}, 3 \mathrm{PhH}) ;{ }^{13} \mathrm{C} \mathrm{NMR}(\delta \mathrm{ppm}): 111.3$ (C-2), 117.5, 127.0, 127.3, 127.7, 127.9, 128.1, 128.4, 128.7, 129.2, 129.6, 132.4, 133.5, 135.3, 142.6, 146.2, 152.5, 156.8, 158.1, $161.8(\mathrm{CO})$; MS: $m / z(\%)=464\left(\mathrm{M}^{+}, 24 \%\right)$; Anal. Calcd. for $\mathrm{C}_{26} \mathrm{H}_{16} \mathrm{~N}_{4} \mathrm{OS}_{2}(464.561): \mathrm{C}, 67.22 ; \mathrm{H}$, 3.47; N, 12.06; S, 13.80. Found: C, 67.05; H, 3.32; N, 11.85; S, 13.61.

Synthesis of 1-amino-6-phenyl-7-(phenylazo)imidazo[1,2-a]thieno[2,3-d]pyrimidine-2,5(1H,3H)-dione (6b):The oxime $6 \mathbf{a}(0.01 \mathrm{~mol})$ in acetic anhydride $(20 \mathrm{ml})$ was refluxed for $3 \mathrm{~h}$. The reaction mixture was then cooled in an ice-bath for $1 \mathrm{~h}$. When the nitrile $\mathbf{6 b}$ started separating, it was collected by filtration. Filtrate was added to icewater $(100 \mathrm{ml})$, and the additional nitrile separated was also collected by filtration. Combined product was dried and recrystallized from aqueous ethanol to give yellowish white crystals of the nitrile $6 \mathbf{b}(0.60 \mathrm{~g} ; 75 \%)$, mp 227-228 C; IR $\left(v / \mathrm{cm}^{-1}\right): 3325,3230\left(\mathrm{NH}_{2}\right), 3052(\operatorname{arom~CH}), 1721,1680(2 \mathrm{CO}) ;{ }^{1} \mathrm{H}$ NMR $\left(\delta\right.$ ppm): $4.80\left(\mathrm{~s}, 2 \mathrm{H}, \mathrm{NH}_{2}, \mathrm{D}_{2} \mathrm{O}-\right.$ exchangeable), 4.92 (s, 2H, imidazole $\left.\mathrm{CH}_{2}\right)$, 7.16-7.48 (m, $10 \mathrm{H}, 2 \mathrm{PhH}$ ); Anal. Calcd. for $\mathrm{C}_{20} \mathrm{H}_{14} \mathrm{~N}_{6} \mathrm{O}_{2} \mathrm{~S}(402.429)$ : $\mathrm{C}$, 59.69; H, 3.51; N, 20.88; S, 7.97. Found: C, 59.46; H, 3.32; N, 20.67; S, 7.81.

\section{Synthesis of 6-phenyl-7-phenylazo-1-(piperidin-1-ylmethyl)imidazo[1,2-a]thieno[2,3-d]pyrimidine- 2,5(1H,3H)-dione (7a):-}

A mixture of compound $3(0.003 \mathrm{~mol})$ and triethylorthoformate $(10 \mathrm{ml})$ was heated at reflux for $12 \mathrm{~h}$. After distillation of the ortho ester, the viscous mass was treated with ether or petroleum ether ( 3 ml). The precipitated crystals of product was filtered off, dried and recrystallized from ethanol/water to give the lactone 7a as orange crystals $(0.73 \mathrm{~g} \mathrm{30 \%})$, mp 270-271 C; IR $\left(v / \mathrm{cm}^{-1}\right): 3062(\operatorname{arom~CH}), 1724,1682(2 \mathrm{CO}) ;{ }^{1} \mathrm{H} \mathrm{NMR}(\delta \mathrm{ppm}): 1.61(\mathrm{~m}$, $\left.6 \mathrm{H}, 3 \mathrm{CH}_{2}\right), 3.15\left(\mathrm{t}, 4 \mathrm{H}, \mathrm{N}\left[\mathrm{CH}_{2}\right]_{2}\right), 4.87\left(\mathrm{~s}, 2 \mathrm{H}\right.$, imidazole $\left.\mathrm{CH}_{2}\right), 4.98\left(\mathrm{~s}, 2 \mathrm{H}, \mathrm{CH}_{2}\right), 7.22-7.50(\mathrm{~m}, 10 \mathrm{H}, 2 \mathrm{PhH}) ; \mathrm{MS}$ : $m / z(\%)=484\left(\mathrm{M}^{+}, 29 \%\right)$; Anal. Calcd. for $\mathrm{C}_{26} \mathrm{H}_{24} \mathrm{~N}_{6} \mathrm{O}_{2} \mathrm{~S}(484.573)$ : C, 64.44; H, 4.99; N, 17.34; S, 6.62. Found: C, $64.23 ; \mathrm{H}, 4.81 ; \mathrm{N}, 17.14 ; \mathrm{S}, 6.51$. 
Synthesis of 2-hydrazinyl-5-phenyl-6-(phenylazo)thieno[2,3-d]pyrimidin-4(3H)-one (7b):-

A mixture of compound $3(0.05 \mathrm{~mol})$ and acetic anhydride $(0.5 \mathrm{~mol})$ was refluxed for $90 \mathrm{~min}$ and then kept aside overnight at room temperature. The excess of acetic anhydride was distilled off under reduced pressure and the residue was dissolved in petroleum ether with stirring. After stirring for $1 \mathrm{~h}$, the solid product was collected by filtration and dried. Recrystallization from acetic anhydride gave the 2-methyl derivative $\mathbf{7 b}$ as a light brown solid $(0.71 \mathrm{~g} ; 65 \%), \mathrm{mp} 253-256 \mathrm{C}$; IR $\left(\mathrm{v} / \mathrm{cm}^{-1}\right): 3380-3237\left(\mathrm{NH}, \mathrm{NH}_{2}\right), 3065$ (arom $\left.\mathrm{CH}\right), 1660(\mathrm{CO}) ;{ }^{1} \mathrm{H} \mathrm{NMR}(\delta \mathrm{ppm})$ : 3.75 (s, 2H, $\mathrm{NH}_{2}, \mathrm{D}_{2} \mathrm{O}$-exchangeable), 7.14-7.44 (m, 10H, 2PhH), $9.23\left(\mathrm{~s}, 1 \mathrm{H}, \mathrm{NH}, \mathrm{D}_{2} \mathrm{O}\right.$-exchangeable), 12.51 (s, $1 \mathrm{H}, \mathrm{CONH}, \mathrm{D}_{2} \mathrm{O}$-exchangeable); ${ }^{13} \mathrm{C}$ NMR $(\delta \mathrm{ppm}): 115.8,127.2,127.6,127.9,128.4,128.8,129.5,132.5,135.1$, 142.5, 152.4, 156.5, 157.0, 160.9 (CO); Anal. Calcd. for $\mathrm{C}_{18} \mathrm{H}_{14} \mathrm{~N}_{6} \mathrm{OS}$ (362.408): C, 59.65; H, 3.89; N, 23.19; $\mathrm{S}$, 8.85. Found: C, 59.43; H, 3.75; N, 23.02; S, 8.65.

\section{Synthesis of 3-methyl-6-phenyl-7-(phenylazo)thieno[2,3-d][1,2,4]triazolo[4,3-a]pyrimidin-5(1H)-one (9a):- Method A:}

A mixture of compound $7 \mathbf{b}(0.005 \mathrm{~mol})$, hydrazine hydrate $(0.05 \mathrm{~mol}, 2.5 \mathrm{ml})$ in absolute ethanol $(12 \mathrm{ml})$ was refluxed for $2 \mathrm{~h}$. After cooling overnight and dilution with water, the separated solid product was collected by filtration, dried and purified by recrystallization from a mixture of ethanol and chloroform (1:1) to give yellow crystals of the $N$-amino compound 9a $(0.62 \mathrm{~g} ; 66 \%), \mathrm{mp} 227-228 \mathrm{C}$; IR $\left(\mathrm{v} / \mathrm{cm}^{-1}\right): 3195(\mathrm{NH}), 3068$ (arom CH), 2210 $(\mathrm{CN}), 1667(\mathrm{CO}) ;{ }^{1} \mathrm{H}$ NMR $(\delta \mathrm{ppm}): 6.87\left(\mathrm{~s}, 1 \mathrm{H}\right.$, pyrrole H-8), 7.13-7.49 $(\mathrm{m}, 15 \mathrm{H}, 3 \mathrm{PhH}), 12.35\left(\mathrm{~s}, 1 \mathrm{H}, \mathrm{NH}, \mathrm{D}_{2} \mathrm{O}-\right.$ exchangeable); MS: $m / z(\%)=471\left(\mathrm{M}^{+}, 23 \%\right)$; Anal. Calcd. for $\mathrm{C}_{28} \mathrm{H}_{17} \mathrm{~N}_{5} \mathrm{OS}(471.532): \mathrm{C}, 71.32 ; \mathrm{H}, 3.63 ; \mathrm{N}, 14.85$; S, 6.80. Found: C, 71.09; H, 3.50; N, 14.63; S, 6.69.

\section{Method B:}

This compound was synthesized from $N$-acetyl derivative $10 \mathbf{a}(0.002 \mathrm{~mol})$ and hydrazine hydrate $(0.02 \mathrm{~mol}, 1 \mathrm{ml})$ in a manner similar to that described above in method A (reaction time: $8 \mathrm{~h}$ ). The material obtained after recrystallization from ethanol and chloroform mixture proved to be $9 \mathbf{a}$ (59\% yield).

Synthesis of 3-acetyl-2-methylthio-5-phenyl-6-(phenylazo)thieno[2,3-d]pyrimidin-4(3H)-one (9b):-

A stirred suspension of glacial acetic acid $(20 \mathrm{ml})$ and ammonium acetate $(0.005 \mathrm{~mol})$, was treated with compound 7b $(0.0025 \mathrm{~mol})$. The mixture was heated at reflux for $3 \mathrm{~h}$ after which it was cooled to room temperature. The material which separated upon cooling was isolated by filtration, dried and purified by recrystallization from a mixture of 1,4-dioxane and dimethylformamide $(3: 1 \mathrm{v} / \mathrm{v})$ to give light brown crystals of the pyrimidinone derivative 9b $(0.62 \mathrm{~g} ; 66 \%), \mathrm{mp} 227-228 \mathrm{C}$; IR $\left(\mathrm{v} / \mathrm{cm}^{-1}\right): 3195(\mathrm{NH}), 3068$ (arom $\left.\mathrm{CH}\right), 2210(\mathrm{CN}), 1667(\mathrm{CO}) ;{ }^{1} \mathrm{H}$ NMR $(\delta$ ppm): $6.87(\mathrm{~s}, 1 \mathrm{H}$, pyrrole $\mathrm{H}-8), 7.13-7.49(\mathrm{~m}, 15 \mathrm{H}, 3 \mathrm{PhH}), 12.35\left(\mathrm{~s}, 1 \mathrm{H}, \mathrm{NH}, \mathrm{D}_{2} \mathrm{O}\right.$-exchangeable $)$; $\mathrm{MS}: \mathrm{m} / z(\%)=$ $471\left(\mathrm{M}^{+}, 23 \%\right)$; Anal. Calcd. for $\mathrm{C}_{28} \mathrm{H}_{17} \mathrm{~N}_{5} \mathrm{OS}$ (471.532): C, 71.32; H, 3.63; N, 14.85; S, 6.80. Found: C, 71.09; H, $3.50 ; \mathrm{N}, 14.63 ; \mathrm{S}, 6.69$.

Synthesis of ethyl 2-(2-oxo-2-phenylethylamino)-4-phenyl-5-(phenylazo)thiophene-3-carboxylate (9c):A mixture of compound $7 \mathbf{b}(0.002 \mathrm{~mol})$ and aniline $(0.004 \mathrm{~mol})$ in $20 \mathrm{ml}$ of acetic acid was refluxed under stirring for $3 \mathrm{~h}$. Upon cooling, a solid was obtained which was isolated by filtration, washed with water, dried and purified by recrystallization from 1,4-dioxane to obtain the title compound $\mathbf{9 c}$ as yellow crystals $(0.87 \mathrm{~g} ; 37 \%)$, mp 233-236 C; IR $\left(v / \mathrm{cm}^{-1}\right): 3163(\mathrm{NH}), 3045(\operatorname{arom~CH}), 1679,1671(2 \mathrm{CO}) ;{ }^{1} \mathrm{H}$ NMR $(\delta \mathrm{ppm}): 1.31(\mathrm{t}, 3 \mathrm{H}, J=7.2 \mathrm{~Hz}$, ester $\mathrm{Me}), 4.45\left(\mathrm{q}, 2 \mathrm{H}, J=7.2 \mathrm{~Hz}\right.$, ester $\left.\mathrm{CH}_{2}\right), 4.91\left(\mathrm{~d}, 2 \mathrm{H}, \mathrm{CH}_{2}\right), 7.28-7.84(\mathrm{~m}, 15 \mathrm{H}, 3 \mathrm{PhH}), 8.25\left(\mathrm{~s}, \mathrm{br}, 1 \mathrm{H}, \mathrm{NH}, \mathrm{D}_{2} \mathrm{O}-\right.$ exchangeable); MS: $m / z(\%)=469\left(\mathrm{M}^{+}, 19 \%\right)$; Anal. Calcd. for $\mathrm{C}_{27} \mathrm{H}_{23} \mathrm{~N}_{3} \mathrm{O}_{3} \mathrm{~S}$ (469.555): C, 69.06; H, 4.94; $\mathrm{N}, 8.95$; S, 6.83. Found: C, 68.82; H, 4.77; N, 8.76; S, 6.67.

\section{Synthesis of ethyl 2-(2-amino-3-cyano-4-phenyl-1H-pyrrol-1-yl)-4-phenyl-5-(phenylazo)thiophene-3- carboxylate (9d):- \\ Method A:}

A mixture of compound $7 \mathbf{b}(0.002 \mathrm{~mol})$ and ethyl glycinate hydrochloride $(0.004 \mathrm{~mol})$ in pyridine $(20 \mathrm{ml})$ was heated at reflux for $4 \mathrm{~h}$. The product formed after cooling was isolated by filtration, dried and purified by recrystallization from ethanol to obtain the title compound $9 \mathbf{d}$ as canary-yellow needles $(0.87 \mathrm{~g} ; 37 \%)$, mp 233-236 C; IR $\left(v / \mathrm{cm}^{-1}\right): 3163(\mathrm{NH}), 3045(\operatorname{arom~CH}), 1679,1671(2 \mathrm{CO}) ;{ }^{1} \mathrm{H}$ NMR $(\delta \mathrm{ppm}): 1.31(\mathrm{t}, 3 \mathrm{H}, J=7.2 \mathrm{~Hz}$, ester $\mathrm{Me}), 4.45\left(\mathrm{q}, 2 \mathrm{H}, J=7.2 \mathrm{~Hz}\right.$, ester $\left.\mathrm{CH}_{2}\right), 4.91\left(\mathrm{~d}, 2 \mathrm{H}, \mathrm{CH}_{2}\right), 7.28-7.84(\mathrm{~m}, 15 \mathrm{H}, 3 \mathrm{PhH}), 8.25\left(\mathrm{~s}, \mathrm{br}, 1 \mathrm{H}, \mathrm{NH}, \mathrm{D}_{2} \mathrm{O}-\right.$ exchangeable); MS: $m / z(\%)=469\left(\mathrm{M}^{+}, 19 \%\right)$; Anal. Calcd. for $\mathrm{C}_{27} \mathrm{H}_{23} \mathrm{~N}_{3} \mathrm{O}_{3} \mathrm{~S}$ (469.555): C, 69.06; H, 4.94; $\mathrm{N}, 8.95$; S, 6.83. Found: C, 68.82; H, 4.77; N, 8.76; S, 6.67. 


\section{Method B:}

To a solution of compound $\mathbf{9 b}(0.003 \mathrm{~mol})$ in dimethylformamide $(20 \mathrm{ml})$, anhydrous potassium carbonate $(0.006$ mol) was added and the mixture was stirred at room temperature for $15 \mathrm{~min}$, followed by the addition of ethyl chloroacetate $(0.0033 \mathrm{~mol})$ in dimethylformamide $(10 \mathrm{ml})$. Stirring was continued at room temperature overnight, according to thin layer chromatographic (TLC) analysis. And then ice/water mixture was added to the reaction mixture to form a precipitate, which was isolated by filtration, washed with water and dried. The residue was recrystallized from ethanol to give a solid product, in 55\% yield, identical in every respect (mp, mixed mp and IR data) to that obtained above from method A.

Synthesis of 4-oxo-3,7-diphenyl-2-phenylazo-4,5-dihydropyrrolo[1,2-a]thieno[3,2-e]pyrimidine-6-carbonitrile (10a):-

A mixture of aminoester $2(0.005 \mathrm{~mol})$ and acetic anhydride $(2 \mathrm{ml})$ was refluxed for $1 \mathrm{~h}$ with constant stirring in acetic acid $(5 \mathrm{ml})$. The mixture was cooled and poured over iced water. The resulting precipitate was filtered off, washed with water and dried. The residue was purified by recrystallization from acetic acid to obtain orange crystals of the acetamidoester10a $(1.94 \mathrm{~g} ; 30 \%)$, mp 227-228 C; IR $\left(v / \mathrm{cm}^{-1}\right): 3412,3325\left(\mathrm{NH}_{2}\right), 3070$ (arom $\left.\mathrm{CH}\right), 2206$ $(\mathrm{CN}), 1730(\mathrm{CO}) ;{ }^{1} \mathrm{H}$ NMR $(\delta \mathrm{ppm}): 1.27\left(\mathrm{t}, 3 \mathrm{H}, J=7.2 \mathrm{~Hz}\right.$, ester Me), $4.39\left(\mathrm{q}, 2 \mathrm{H}, J=7.2 \mathrm{~Hz}\right.$, ester $\left.\mathrm{CH}_{2}\right), 6.31(\mathrm{~s}$, br, $2 \mathrm{H}, \mathrm{NH}_{2}, \mathrm{D}_{2} \mathrm{O}$-exchangeable), $6.98(\mathrm{~s}, 1 \mathrm{H}$, pyrrole $\mathrm{H}-5), 7.11-7.52(\mathrm{~m}, 15 \mathrm{H}, 3 \mathrm{PhH})$; Anal. Calcd. for $\mathrm{C}_{30} \mathrm{H}_{23} \mathrm{~N}_{5} \mathrm{O}_{2} \mathrm{~S}$ (517.601): C, 69.61; H, 4.48; N, 13.53; S, 6.19. Found: C, 69.42; H, 4.33; N, 13.28; S, 6.07.

Synthesis of 4-oxo-3,7-diphenyl-2-phenylazo-4,5-dihydropyrrolo[1,2-a]thieno[3,2-e]pyrimidine-6-carbonitrile (10b):-

Compound $2(0.005 \mathrm{~mol})$ was mixed with an equivalent amount of phenyl isothiocyanate in ethanol $(12 \mathrm{ml})$. The reaction content was heated at reflux for $5 \mathrm{~h}$. A crude solid product, formed while hot, was filtered off, dried and purified by recrystallization from ethanol to give yellowish white needles of the title compound 10b (1.94 g; 30\%), mp 227-228 C; IR $\left(v / \mathrm{cm}^{-1}\right): 3412,3325\left(\mathrm{NH}_{2}\right), 3070(\operatorname{arom~CH}), 2206(\mathrm{CN}), 1730(\mathrm{CO}) ;{ }^{1} \mathrm{H}$ NMR $(\delta \mathrm{ppm}): 1.27(\mathrm{t}$, $3 \mathrm{H}, J=7.2 \mathrm{~Hz}$, ester Me), 4.39 (q, $2 \mathrm{H}, J=7.2 \mathrm{~Hz}$, ester $\mathrm{CH}_{2}$ ), 6.31 (s, br, $2 \mathrm{H}, \mathrm{NH}_{2}, \mathrm{D}_{2} \mathrm{O}$-exchangeable), $6.98(\mathrm{~s}, 1 \mathrm{H}$, pyrrole $\mathrm{H}-5)$, 7.11-7.52 (m, $15 \mathrm{H}, 3 \mathrm{PhH})$; Anal. Calcd. for $\mathrm{C}_{30} \mathrm{H}_{23} \mathrm{~N}_{5} \mathrm{O}_{2} \mathrm{~S}(517.601)$ : C, 69.61; H, 4.48; N, 13.53; $\mathrm{S}$, 6.19. Found: C, 69.42; H, 4.33; N, 13.28; S, 6.07.

Synthesis of 6-phenyl-7-(phenylazo)imidazo[1,2-a]thieno[2,3-d]pyrimidine-2,5(1H,3H)-dione (11a):-

This compound was synthesized from thioureido derivative 10b in a manner similar to that described before for the synthesis of compound 9a (reaction time: $10 \mathrm{~h}$ ). It was recrystallized from dimethylformamide to give the title compound 11a $(1.94 \mathrm{~g} ; 30 \%)$. Alternatively, the same product was obtained, in a comparable yield, using thione derivative 12 instead of compound 10b. This product was isolated as a bright yellow solid, mp 270-271 C; IR $\left(\mathrm{v} / \mathrm{cm}^{-}\right.$ $\left.{ }^{1}\right)$ : $3315(\mathrm{NH}), 3056(\operatorname{arom~CH}), 1710,1680(2 \mathrm{CO}) ;{ }^{1} \mathrm{H}$ NMR $(\delta \mathrm{ppm}): 4.89\left(\mathrm{~s}, 2 \mathrm{H}\right.$, imidazole $\left.\mathrm{CH}_{2}\right), 7.19-7.48(\mathrm{~m}$, $10 \mathrm{H}, 2 \mathrm{PhH}), 11.83\left(\mathrm{~s}, 1 \mathrm{H}, \mathrm{NH}, \mathrm{D}_{2} \mathrm{O}\right.$-exchangeable); MS: $\mathrm{m} / \mathrm{z}(\%)=387\left(\mathrm{M}^{+}, 14 \%\right)$; Anal. Calcd. for $\mathrm{C}_{20} \mathrm{H}_{13} \mathrm{~N}_{5} \mathrm{O}_{2} \mathrm{~S}(387.415)$ : C, 62.00; H, 3.38; N, 18.08; S, 8.28. Found: C, 61.76; H, 3.21; N, 17.90; S, 8.14.

\section{Synthesis of 6-phenyl-7-(phenylazo)imidazo[1,2-a]thieno[2,3-d]pyrimidine:-}

2,5(1H,3H)-dione (11b):-

Compound 11a $(0.003 \mathrm{~mol})$ was dissolved in acetic acid $(20 \mathrm{ml})$, a small amount of insoluble material was filtered off, then the liquid was cooled in ice bath at $0-5{ }^{\circ} \mathrm{C}$. The solution was stirred at this temperature and treated gradually with a cold saturated solution of sodium nitrite [ $1 \mathrm{~g}$ of sodium nitrite $(0.015 \mathrm{~mol})$ in water $(10 \mathrm{ml})]$ over a period of $15 \mathrm{~min}$. Stirring was continued for further $30 \mathrm{~min}$, then the reaction mixture was left to stand at room temperature for $3 \mathrm{~h}$. The resulting solid was filtered off, washed with water and dried. Recrystallization from ethanol gave the title compound 11b as a reddish brown solid $(0.80 \mathrm{~g} ; 69 \%), \mathrm{mp} 270-271 \mathrm{C}$; IR $\left(\mathrm{v} / \mathrm{cm}^{-1}\right): 3315(\mathrm{NH}), 3056$ $(\operatorname{arom~CH}), 1710,1680(2 \mathrm{CO}) ;{ }^{1} \mathrm{H}$ NMR $(\delta \mathrm{ppm}): 4.89\left(\mathrm{~s}, 2 \mathrm{H}\right.$, imidazole $\left.\mathrm{CH}_{2}\right), 7.19-7.48(\mathrm{~m}, 10 \mathrm{H}, 2 \mathrm{PhH}), 11.83(\mathrm{~s}$, $1 \mathrm{H}, \mathrm{NH}, \mathrm{D}_{2} \mathrm{O}$-exchangeable); MS: $\mathrm{m} / z(\%)=387\left(\mathrm{M}^{+}, 14 \%\right)$; Anal. Calcd. for $\mathrm{C}_{20} \mathrm{H}_{13} \mathrm{~N}_{5} \mathrm{O}_{2} \mathrm{~S}(387.415)$ : $\mathrm{C}, 62.00 ; \mathrm{H}$, 3.38; N, 18.08; S, 8.28. Found: C, 61.76; H, 3.21; N, 17.90; S, 8.14.

Synthesis of 4-oxo-3,7-diphenyl-2-phenylazo-4,5-dihydropyrrolo[1,2-a]thieno[3,2-e]pyrimidine-6-carbonitrile (12):-

To a solution of compound $3(0.005 \mathrm{~mol})$ in $30 \mathrm{ml}$ of dimethylformamide, phenyl isothiocyanate $(0.0056 \mathrm{~mol})$ was added dropwise. The reaction content was heated at reflux for $24 \mathrm{~h}$. After cooling to room temperature, the solvent was removed in vacuoand the crude solid product was filtered off, dried and purified by recrystallization from ethanol to give light brown crystals of the title compound 12 (1.94 g; 30\%), mp 227-228 C; IR $\left(v / \mathrm{cm}^{-1}\right): 3412,3325$ 
$\left(\mathrm{NH}_{2}\right), 3070(\operatorname{arom~CH}), 2206(\mathrm{CN}), 1730(\mathrm{CO}) ;{ }^{1} \mathrm{H}$ NMR $(\delta \mathrm{ppm}): 1.27$ (t, 3H, $J=7.2 \mathrm{~Hz}$, ester Me), $4.39(\mathrm{q}, 2 \mathrm{H}, J$ $=7.2 \mathrm{~Hz}$, ester $\left.\mathrm{CH}_{2}\right), 6.31\left(\mathrm{~s}, \mathrm{br}, 2 \mathrm{H}, \mathrm{NH}_{2}, \mathrm{D}_{2} \mathrm{O}\right.$-exchangeable), $6.98(\mathrm{~s}, 1 \mathrm{H}$, pyrrole $\mathrm{H}-5), 7.11-7.52(\mathrm{~m}, 15 \mathrm{H}$, 3PhH); Anal. Calcd. for $\mathrm{C}_{30} \mathrm{H}_{23} \mathrm{~N}_{5} \mathrm{O}_{2} \mathrm{~S}$ (517.601): C, 69.61; H, 4.48; N, 13.53; S, 6.19. Found: C, 69.42; H, 4.33; N, $13.28 ; \mathrm{S}, 6.07$.

\section{Scheme 1:-}

Reagents and conditions: (a) $\mathrm{H}_{2} \mathrm{NCH}_{2} \mathrm{CO}_{2} \mathrm{Et}$, DMF, $\mathrm{K}_{2} \mathrm{CO}_{3}$, reflux; (b) $\mathrm{H}_{2} \mathrm{NCH}_{2} \mathrm{CO}_{2} \mathrm{H}, \mathrm{DMF}, \mathrm{K}_{2} \mathrm{CO}_{3}$, reflux; (c) (i) $\mathrm{KOH}$, ab. EtOH, reflux; (ii) $\mathrm{AcOH}$ (hydrolysis); (d) $\mathrm{HCONH}_{2}$, reflux; (e) (i) $\mathrm{POCl}_{3}-\mathrm{DMF}$ (Vilsmeier-Haack reagent), reflux; (ii) aq. $\mathrm{NaOH}$ (hydrolysis); (f) $\mathrm{H}_{2} \mathrm{NOH} . \mathrm{HCl}$, gl. $\mathrm{AcOH}, \mathrm{H}_{2} \mathrm{O}$; (g) $\mathrm{Ac}_{2} \mathrm{O}$, reflux.

Fig. 1:-Tautomeric structures of compound 3.

Fig. 2:- Proposed mechanism for conversion of 2-unsubstituted pyrimidinone 3 to the corresponding 2-carbaldehyde analogue 4. 
Scheme 2:-

Reagents and conditions: (a) PhNCS, EtOH, reflux; (b) $\mathrm{H}_{2} \mathrm{NNH}_{2} \cdot \mathrm{H}_{2} \mathrm{O}$, ab. EtOH, reflux; (c) $\mathrm{NaNO}_{2}, \mathrm{AcOH}, 0-5{ }^{\circ} \mathrm{C}$; (d) PhNCS, DMF, reflux.

\section{Scheme 2:-}


Reagents and conditions: (a) PhNCS, EtOH, reflux; (b) $\mathrm{H}_{2} \mathrm{NNH}_{2} \cdot \mathrm{H}_{2} \mathrm{O}$, ab. EtOH, reflux; (c) $\mathrm{NaNO}_{2}, \mathrm{AcOH}, 0-5{ }^{\circ} \mathrm{C}$; (d) PhNCS, DMF, reflux.

Scheme 3:-

Reagents and conditions: (a) $\mathrm{HC}(\mathrm{OEt})_{3}$, reflux; (b) $\mathrm{Ac}_{2} \mathrm{O}$, reflux; (c) $\mathrm{PhCOCl}$, dry pyridine, $0-5{ }^{\circ} \mathrm{C}$ then r.t.; (d) $\mathrm{H}_{2} \mathrm{NNH}_{2} . \mathrm{H}_{2} \mathrm{O}$, ab. EtOH, reflux; (e) $\mathrm{MeCO}_{2} \mathrm{NH}_{4}$, AcOH, reflux; (f) $\mathrm{PhNH}_{2}, \mathrm{AcOH}$, reflux; (g) $\mathrm{H}_{2} \mathrm{NCH}_{2} \mathrm{CO}_{2} \mathrm{Et}$, EtOH, reflux; (h) $\mathrm{NaNO}_{2}, \mathrm{AcOH}, 0-5{ }^{\circ} \mathrm{C}$; (i) $\mathrm{ClCH}_{2} \mathrm{CO}_{2} \mathrm{Et}$, DMF, $\mathrm{K}_{2} \mathrm{CO}_{3}$, r.t.

r.t. $=$ room temperature

Fig. 3:- Proposed mechanism for conversion of 2-thioxo-3-phenylpyrimidinone 8 to the corresponding 2phenylamino-3-amino analogue $7 \mathbf{a}$. 


\section{Biorationalactivity:- \\ Rearing mosquitoes:-}

Fourth-instar larvae of Culexpipienswere obtained from a laboratory colony at Entomology Department, Faculty of Science, Cairo University. Larvae were placed in Pyrex storage jars containing $200 \mathrm{ml}$ of tap water. The colonies of mosquitoes were maintained at $25 \pm 2{ }^{\circ} \mathrm{C}$ and $60 \pm 5 \%$ relative humidity, and under 14: $10 \mathrm{~h}$ light: dark photoperiod cycle. Larvae were daily fed with fresh food consists in a mixture of Biscuit Petit regal-dried yeast (75:25 by weight) and water was replaced every four days. Colony was continuously as previously described (14) with some modification.

\section{Treatment of Larvae:-}

Twenty five fourth instars larvae of $C$. pipiens, were exposed to three concentrations $(0.25 ; 0.50$; and $0.75 \%)$ of different pyridine compounds. The treatment has been done under laboratory conditions, according to standard World Health Organization (WHO) methodology (15). Larvae were placed in glass beakers containing $200 \mathrm{ml}$ water. Serial dilution of pyridine compounds (from 1 to 11 compounds) were prepared in distillate water and added to the treatment beakers, then added a food source to larvae. Control larvae were reared in jars containing only water. The effects of pyridine compounds were assessed by biorational effect on larvae after 24 hours in parallel with control experiment.

\section{Statistical Analysis:-}

The larval mortality was corrected by (16) formula if control mortality was between. Toxicity data were studies by probit analysis (17). The probits regression program was used to determine the $\mathrm{LC}_{\mathbf{5 0}}$.

\section{Results and Discussion:- Chemical compounds:-}

Heterocyclization of ethylthio derivative 1 [14] with ethyl glycinate was carried out to afford a bicyclic product for which the pyrrolopyridine2a with $o$-aminoesterstructurewas established on the basis of spectroscopic studies. The IR spectrum of the latter product showed no nitrile absorption, but a carbonyl absorption was observed at $v 1664 \mathrm{~cm}^{-1}$ corresponding to a chelated conjugated ester. Similarly, the ${ }^{1} \mathrm{H}$ NMR spectrum was also informative in establishing the structure of aminoester2a. The spectrum was well characterized by the presence of two $\mathrm{D}_{2} \mathrm{O}$-exchangeable signals arising from the exocyclic $\mathrm{NH}_{2}$ and endocyclic $\mathrm{NH}$ protons at $\delta_{\mathrm{H}} 6.30$ and $11.17 \mathrm{ppm}$, respectively, besides signals for the expected protons of an ethyl ester and aryl moieties. Alkaline hydrolysis of ethyl ester $\mathbf{2 a}$ followed by acidification gave the corresponding carboxylic acid $\mathbf{2 b}$. It is worth mentioning that the same product $\mathbf{2 b}$ could also be obtained directly by reacting compound $\mathbf{1}$ with glycine. Compound $\mathbf{2 b}$ prepared by the latter route was found to be identical to that isolated by the former method as confirmed by TLC analysis, m.p., IR data and undepressed mixed melting point with the previously isolated material. Treating aminoester $\mathbf{2 a}$ with formamide led to closure of the pyrimidine ring and accordingly led to the formation of the tricyclic pyridinopyrrolopyrimidine derivative $\mathbf{3}$ (Scheme 1). Compound $\mathbf{3}$ might be exist in one or more of three tautomeric structures A-C (Fig. 1). The most stable tautomeric form for compound 3 was determined through the analysis of IR and ${ }^{1} \mathrm{H}$ NMR spectral data. The possibility of the tautomerism involving lactim (enol) form $\mathbf{3 C w a s}$ excluded by the evident absence of typical signals for a hydroxylic group in the IR and ${ }^{1} \mathrm{H}$ NMR spectra. In the ${ }^{1} \mathrm{H}$ NMR spectrum, the most diagnostic signal is due to the $\mathrm{NH}$ proton (exchangeable with $\mathrm{D}_{2} \mathrm{O}$ ). The spectrum showed this proton, appearing in the downfield region $\left(\delta_{\mathrm{H}} 12.42 \mathrm{ppm}\right.$ ) typical for an 3-unsubstituted lactam (keto) form $\mathbf{3 A}$, where the $\mathrm{NH}$ proton was deshielded by the adjacent carbonyl group. This shift is characteristic for lactam species, for which a lactam NH group has been reported [15-18a,b] to experience a further downfield shift to around $\delta_{\mathrm{H}} \sim 12.00 \mathrm{ppm}$ due to the additional deshielding effect of the adjacent carbonyl moiety. On the contrary, the alternative tautomeric $1 H$-form 3B, if isolated, should lead to an upfield shift at N-1-unsubstituted resonance position due to the lesser deshielding effect. As a result, the $\mathrm{NH}$ proton of $1 \mathrm{H}$-form $\mathbf{3 B}$ would be expected to appear at a lower chemical shift value $\left(\delta_{\mathrm{H}}<12.00\right.$ $\mathrm{ppm}$ ) than the corresponding one for tautomeric $3 \mathrm{H}$-form $\mathbf{3 A}$ that have a lactam proton with a greater deshielding effect. The prevalence of the lactam (keto) form in compound $\mathbf{3}$ was further verified based on its IR spectrum. The spectrum was well characterized by the presence of a strong band for the lactam carbonyl group at a typical low frequency $\left(v 1659 \mathrm{~cm}^{-1}\right)$ together with an absorption band for the cyclic secondary amide at $v 3175 \mathrm{~cm}^{-1}$. Similar stretching frequencies have been reported on closely related heterocyclic amido compounds [21a,c-22].The prevalence of the $3 \mathrm{H}$ - rather than the $1 \mathrm{H}$-form in a number of 3-unsubstituted pyrimidin-4-ones is well documented $[18,19,20$ and 26]. These findings affirm that the isolated product exists mainly in one tautomeric form, namely lactam (keto) form 3A. Vilsmeier-Haackformylation of compound 3, using two molar equivalent amount of the 
Vilsmeier-Haack reagent, occurred not only with the formation of an aldehyde group in the 2-position of the pyrimidine ring but also with the chlorination of the amidic carbonyl function, leading eventually to the tricyclic chloroaldehyde analogue $\mathbf{4}$ as evidenced by elemental and spectroscopic investigations. In its IR spectrum, an aldehydic functional group was clearly observed with a carbonyl absorption frequency at $v 1691 \mathrm{~cm}^{-1}$. Moreover, the ${ }^{1} \mathrm{H}$ NMR spectrum of the isolated product could give unequivocal proof for its structure by the observation of a new diagnostic signal, due to the aldehyde proton, appearing in a typical downfield region $\left(\delta_{\mathrm{H}} 10.06 \mathrm{ppm}\right)$. These assignments are in line with prior observations of spectra of analogous heterocyclic aldehydes [27, 28]. The absence of signals belonging to the protons of the pyrimidine methine and amidic $\mathrm{NH}$, present in the spectrum of the parent lactam 3, also lent additional support to the structural assignments. The structural elucidation of the reaction product 4 revealed that the electrophilic attack of the Vilsmeier reagent took place on the C-2 methine atom of compound $\mathbf{3}$, generating an enamine salt 3', which after hydrolysis yielded the corresponding chloroaldehyde compound 4 (Fig. 2 ). This assumption is consistent with the prior findings of related reports on the well establishedVilsmeierHaackformylations [27-30].

The constitution of aldehyde 4 was also well supported by its conversion, on treatment with hydroxylamine hydrochloride, to the corresponding oxime 5a, which in turn was dehydrated by the action of acetic anhydride to form the required nitrile $\mathbf{5 b}$ (Scheme 1). The IR spectrum of the latter product $\mathbf{5 b}$ lacked an absorption band due to the hydroxylic group, but contained stretching frequency at $v 2240 \mathrm{~cm}^{-1}$ characteristic for a CN frequency. Also, the resonances of the hydroxy and methine protons, present in the ${ }^{1} \mathrm{H}$ NMR spectrum of the original oxime5a, were not detectable for the isolated product $\mathbf{5 b}$, providing confirmatory evidence in support of nitrile formation through dehydration. This observation is also supported by previous literature reports on a similar transformation of an aldehyde moiety to a nitrile group in closely related systems via an oximation/dehydration sequence [31, 32].

The bicyclic $o$-aminoester2a proved to be a useful precursor for the synthesis of other tricyclic pyrimidinones (Scheme 2). Thus, a new $\mathrm{N}$-aminolactam7a could also be synthesized via initial treatment of compound 2a with phenyl isothiocyanate, followed by subsequent cyclization of the isolated thiourea product 6a with hydrazine hydrate via loss of hydrogen sulfide. Nevertheless, the configuration of the previously isolated 2phenylaminopyrimidine derivative 7a with $\mathrm{N}$-3-aminolactam structurewas further supported chemically by its successful deamination, where treatment of compound 7a with sodium nitrite and acetic acid led to the corresponding 3-protodeamino analogue 7b. ${ }^{1} \mathrm{H}$ NMR spectroscopy could firmly confirm the structure of theseproducts. The resonance of amino protons allowed us to identify the latter products. In the amino derivative 7a, the N-3-amino protons appeared as a $\mathrm{D}_{2} \mathrm{O}$-exchangeable singlet resonating at a typical shift $\left(\delta_{\mathrm{H}} 5.82 \mathrm{ppm}\right)$ characteristic for an $\mathrm{N}-\mathrm{NH}_{2}$ resonance, whereas the corresponding deamino analogue $\mathbf{7 b}$ showed no $\mathrm{N}-\mathrm{NH}_{2}$ resonance, which is generally found at around $\delta_{\mathrm{H}} \sim 5.75 \mathrm{ppm}$ by analogy with related N-3-aminoquinazolin-4-one analogues $[13,33]$, thus indicating the disappearance of that $\mathrm{N}-3$-amino group in the spectrum of $\mathbf{7 b}$. The remaining resonances were also observed at the expected frequencies (see Experimental section). In addition, the mass spectrum of compound $\mathbf{7 b}$ showed a molecular ion peak at $\mathrm{m} / \mathrm{z} 563$ corresponding to its molecular weight, which is indicative of an decrease of 15 mass units from the parent $\mathbf{7 a}$, confirming the assigned structure. This observation is also supported by prior literature reports on the well established nitrous acid deamination of the exocyclic amino group in closely related cyclic $\mathrm{N}$-aminoamides [34-37].

The bicyclic $o$-aminocarboxylic acid $\mathbf{2 b}$ has also been employed as a synthetic foundation for the target condensed pyrimidine system with the common 7,9-diphenyl-8-(4-methoxyphenylazo) substitution pattern. Thus for example, heterocyclization of compound $\mathbf{2 b}$ with phenyl isothiocyanate was carried out to afford a tricyclic product with an annelated pyrimidine ring for which the thione structure $\mathbf{8}$ could be formulated (Scheme 2). It is remarkable to report here that an unexpected reaction took place on reacting compound $\mathbf{8}$ with hydrazine hydrate in an attempt to obtain the hydrazino compound $\mathbf{9}$. To our surprise, this reaction did not give the anticipated product $\mathbf{9}$ and instead the phenylamino derivative 7a was again isolated, the structure of which was unambiguously confirmed by comparison of TLC analysis, m.p., mixed m.p. and IR data with that of the previously obtained sample 7a. This result can be explained, as illustrated in Figure 3, by assuming that the reaction occurs firstly with the anticipated formation of the hydrazino compound 9, that underwent a Dimroth-type rearrangement [12, 37 and 38] in which the initially formed product 9 was subsequently hydrolyzed to the final rearranged phenylamino derivative $7 \mathbf{a}$ via $\mathrm{N}$-phenyllactam ring opening, followed by dehydrativerecyclization of the acyclic acid intermediate 9 '.

On the other hand, heterocyclization of carboxylic acid $\mathbf{2 b}$ with one-carbon building blocks such as triethylorthoformate and benzoyl chloride afforded lactones $\mathbf{1 0 a}, \mathbf{b}$, whereas acetylation of compound $\mathbf{2 b}$ with acetic 
anhydride readily occurred with the formation of the corresponding 2-methyl analogue 10c, which could be transformed to the desired tricyclic pyrimidinones upon treatment with different nitrogen nucleophiles (Scheme 3). On reaction with hydrazine hydrate, the lactone 10c gave a product which might be assigned the structure of an N-3aminolactam 12a. The pathway of the studied reaction is two-step processes and probably involves initial nucleophilic attack by the amino group of hydrazine hydrate on the electrophilic carbonyl carbon center (C-4 carbon) with subsequent cleavage of the $\mathrm{C}-\mathrm{O}$ bond and as a result the oxazinone ring opening leads to the intermediate formation of acyclic bisamide adduct 11a. Subsequent recyclization could then take place via nucleophilic attack by the carbohydrazide NH moiety on the amidic carbonyl group. This would be accompanied by cyclodehydration, leading eventually to the pyridopyrrolopyrimidine12a with $\mathrm{N}-3$-aminolactam structure. The results of several investigations reported recently support this hypothesis [39-42]. It is worth mentioning that Naminolactam structure 12a was confirmed by an alternative synthetic route involving initial acetylation of the ester 2a with acetic anhydride and subsequent cyclization of the formed $\mathrm{N}$-acetyl derivative $\mathbf{6} \mathbf{b}$ with hydrazine hydrate. Obviously, this reaction could also proceed, in this case, through the intermediacy of the carbohydrazide11a followed by intramolecular cyclocondensation under the applied reaction conditions. Compound 12a prepared by the latter route was found to be identical to that obtained by the former method.

As discussed above, tricyclic pyrimidinone analogues $\mathbf{1 2 b}-\mathbf{d}$ could also be obtained in a similar manner by reacting compound 10c with each of ammonium acetate, aniline and ethyl glycinate, respectively. By analogy with hydrazine, intermediacy of open chain bisamides11b-d, respectively, are most likely. This would also be followed by dehydrativerecyclization, giving the target condensed pyrimidinones12b-d, respectively. Alternative synthesis of $\mathrm{N}$-deamino derivative 12b was achieved by its deamination through treating $\mathrm{N}$-amino compound 12a with sodium nitrite and acetic acid. Furthermore, another synthesis of $\mathrm{N}$-alkylated compound 12d involved the alkylation of 3unsubstituted pyrimidinone derivative 12b with ethyl chloroacetate in the presence of potassium carbonate (Scheme 3 ). Better yield of the required product was obtained in this case. Elucidation of structure for the latter products was established on the basis of elemental and spectroscopic analyses in each case.

Bioassay of the novel pyridopyrrolopyrimidine on the $4^{\text {th }}$ larval instars of the Culexpipiens:-

This study was obviously the pyridine chemical compounds, from 1- 11 have distinct biological effects on theculexpipens larvae. The lethal effect of these compounds was gradually increased by increasing concentrations of each compounds. Exposure of early fourth instar larvae of $C$. pipiensto the different concentrations of pyridine compounds caused a significant larvicidal effect (Table 1). At the lower concentration $0.25 \%$, the larval mortality was lower corresponding to $0.75 \%$. The lethal concentration of pyridine compounds, 1, 2, 3 and 4 produced 67 , 58,85 , and $95 \%$ of larval mortality at the higher concentration $(0.75 \%)$ respectively. The population, $\mathrm{LC}_{\mathbf{5 0}}$ is determined from regression line measured as $0.61,0.72,0.43$ and 0.22 of the previous compounds. Most of deaths at higher concentrations occurred in larvae produced deformation stages as larval- pupal intermediates.

The Biorational assessment of the chemical compounds in Tables 1. As shown by these results, the new condensed tricyclic pyrimidine derivatives under investigation displayed variable biorational effects. In general, the chemical structure, comprising the nature of the heterocyclic system as well as the substituted function present in the heterocyclic ring, has a pronounced effect on insecticidal activity. In particular, it was found that the attachment of a chloro moiety to the pyridopyrrolopyrimidine core produced the highest effects on mosquitoes (Culexpipiens) as observed for 4-chloro compounds $\mathbf{4}, \mathbf{5 a}$ and $\mathbf{5 b}$, with $\mathrm{LC}_{50}$ values $0.43,0.61$ and $0.22 \%$, respectively (Table 1).

The lethal effect of those derivatives was gradually increased by increasing concentrations of each compound. Exposure of early fourth instar larvae of $C$. pipiensto the different concentrations of condensed pyrimidine compounds caused a significant larvicidal effect (Table 1). At the lower concentration $0.25 \%$, the larval mortality was lower corresponding to $0.75 \%$. Most of deaths at higher concentrations occurred in larvae produced deformation stages as larval-pupal intermediates. Based on the biorational evaluation, 4-chloro compound $\mathbf{5 b}$ was the highest toxic and hence could be considered as a lead compound in this field. Similar compounds $\mathbf{4}$ and $\mathbf{5 a}$ showed also high toxicity. Other compounds $\mathbf{3}, \mathbf{7 a}, \mathbf{b}, \mathbf{8}$ and 12a-d were strikingly less toxic than those 4-chloro compounds. This would be as a result of something in the combination of pyridine with pyrrole and pyrimidine without a chlorine moiety.

From the structure-activity relationship (SAR), we can conclude that the chloro moiety is important for insecticidal activity, especially against the Culexpipiens larvae as observed for compound $\mathbf{5 b}$. Further studies are in progress on 
that compound to increase its efficacy and understand its QSAR. The overall results of the present study can be considered promising in the perspective of new insecticides discovery.

Pyridine compounds proved to be highly efficient to the C. pipiens (43 and 44). $\mathrm{LC}_{\mathbf{5 0}}$ values due to effect pyridine derivatives on C. pipienswere 60 and 43\% (47). Our results were comparable with findingsfrom other researchers as the Pyridine solution (5) with sculpture, was highest their toxic compound to Culexlarvae in comparison with other compounds of pyridine base at the same concentrations. Experiments of pyrrolidine of concentration show the compound (4) was highly toxic may due chlorine attached to pyrimidine. The other chemical compounds of pyridine compounds, are strikingly less toxic than compounds (1,2,3 and 4) which results from something in the combination of pyridine with pyrrole and pyrimidine without sulphure and chlorine groups.

In harmony to these results, the idea that nicotine attached to pyridine is more effective against insects than its salts. (44) reported some experiments in which silkworms (BombyxmoriL.) were sprayed with aqueous solutions of nicotine, nicotine containing alkali, and nicotine containing acid. No differences were noticed in the effects produced, but the acidulated nicotine was less active than the other solutions, while free nicotine is more toxic than nicotine salts.

Table 1:-Bioactivity of some novel chemicals on culexpipiense.

\begin{tabular}{|c|c|c|c|c|}
\hline \multirow{2}{*}{$\begin{array}{l}\text { Chemical } \\
\text { compound }\end{array}$} & \multirow[t]{2}{*}{ \% Concent. } & \multicolumn{2}{|c|}{ \%Larval mortality } & \multirow[b]{2}{*}{$\mathrm{LC}_{50}$} \\
\hline & & $12 \mathrm{hrs}$ & & \\
\hline 1 & $\begin{array}{l}0.25 \\
0.5 \\
0.75\end{array}$ & $\begin{array}{l}8.0 \\
9.0 \\
12\end{array}$ & $\begin{array}{l}30 \\
48 \\
67\end{array}$ & 0.61 \\
\hline 2 & $\begin{array}{l}0.25 \\
0.5 \\
0.75\end{array}$ & $\begin{array}{l}6.0 \\
10 \\
15\end{array}$ & $\begin{array}{l}20 \\
36 \\
58\end{array}$ & 0.72 \\
\hline 3 & $\begin{array}{l}0.25 \\
0.5 \\
0.75\end{array}$ & $\begin{array}{l}11 \\
13 \\
21\end{array}$ & $\begin{array}{l}40 \\
55 \\
85\end{array}$ & 0.43 \\
\hline 4 & $\begin{array}{l}0.25 \\
0.5 \\
0.75\end{array}$ & $\begin{array}{l}15 \\
19 \\
22\end{array}$ & $\begin{array}{l}50 \\
75 \\
95\end{array}$ & 0.22 \\
\hline 5 & $\begin{array}{l}0.25 \\
0.5 \\
0.75\end{array}$ & $\begin{array}{l}15 \\
19 \\
22\end{array}$ & $\begin{array}{l}20 \\
35 \\
45\end{array}$ & 0.82 \\
\hline 6 & $\begin{array}{l}0.25 \\
0.5 \\
0.75\end{array}$ & $\begin{array}{l}15 \\
19 \\
22 \\
\end{array}$ & \begin{tabular}{l|l|}
11 \\
18 \\
24
\end{tabular} & 2.4 \\
\hline 7 & $\begin{array}{l}0.25 \\
0.5 \\
0.75\end{array}$ & $\begin{array}{l}15 \\
19 \\
22\end{array}$ & $\begin{array}{l}17 \\
21 \\
35\end{array}$ & 1.3 \\
\hline 8 & $\begin{array}{l}0.25 \\
0.5 \\
0.75\end{array}$ & $\begin{array}{l}15 \\
19 \\
22\end{array}$ & $\begin{array}{l}22 \\
31 \\
42\end{array}$ & 0.93 \\
\hline 9 & $\begin{array}{l}0.25 \\
0.5 \\
0.75\end{array}$ & $\begin{array}{l}15 \\
19 \\
22\end{array}$ & $\begin{array}{l}23 \\
27 \\
34\end{array}$ & 1.4 \\
\hline 10 & $\begin{array}{l}0.25 \\
0.5 \\
0.75\end{array}$ & $\begin{array}{l}15 \\
19 \\
22\end{array}$ & $\begin{array}{l}21 \\
27 \\
36\end{array}$ & 1.2 \\
\hline 11 & $\begin{array}{l}0.25 \\
0.5 \\
0.75\end{array}$ & $\begin{array}{l}15 \\
19 \\
22\end{array}$ & $\begin{array}{l}40 \\
55 \\
85\end{array}$ & 1.3 \\
\hline
\end{tabular}


The Biorational assessment of the chemical compounds in Tables 1. As shown by these results, the new condensed tricyclic pyrimidine derivatives under investigation displayed variable biorational effects. In general, the chemical structure, comprising the nature of the heterocyclic system as well as the substituted function present in the heterocyclic ring, has a pronounced effect on insecticidal activity. In particular, it was found that the attachment of a chloro moiety to the pyridopyrrolopyrimidine core produced the highest effects on mosquitoes (Culexpipiens) as observed for 4-chloro compounds 4, 5a and $\mathbf{5 b}$, with $\mathrm{LC}_{50}$ values $0.43,0.61$ and $0.22 \%$, respectively (Table 1).

The lethal effect of those derivatives was gradually increased by increasing concentrations of each compound. Exposure of early fourth instar larvae of $C$. pipiensto the different concentrations of condensed pyrimidine compounds caused a significant larvicidal effect (Table 1). At the lower concentration $0.25 \%$, the larval mortality was lower corresponding to $0.75 \%$. Most of deaths at higher concentrations occurred in larvae produced deformation stages as larval-pupal intermediates. Based on the biorational evaluation, 4-chloro compound $\mathbf{5 b}$ was the highest toxic and hence could be considered as a lead compound in this field. Similar compounds $\mathbf{4}$ and $\mathbf{5 a}$ showed also high toxicity. Other compounds $\mathbf{3}, \mathbf{7 a}, \mathbf{b}, \mathbf{8}$ and 12a-d were strikingly less toxic than those 4-chloro compounds. This would be as a result of something in the combination of pyridine with pyrrole and pyrimidine without a chlorine moiety.

From the structure-activity relationship (SAR), we can conclude that the chloro moiety is important for insecticidal activity, especially against the Culexpipiens larvae as observed for compound $\mathbf{5 b}$. Further studies are in progress on that compound to increase its efficacy and understand its QSAR. The overall results of the present study can be considered promising in the perspective of new insecticides discovery.

\section{Conclusion:-}

We have demonstrated that the heterocyclization of 2-aminopyrrolopyridine-3-carboxylate and -2-carboxylic acid derivatives $\mathbf{2}$ and $\mathbf{3}$ provided easy and versatile access to a variety of tricyclic pyrimidines, which were of significant interest for biorational investigations. The biorational potential of all new tricyclic pyrimidine derivatives was further investigated by evaluating their insecticidal activity against Culexpipiens larvae. Biorational study of the compounds under investigation indicated that the highest insecticidal activity was observed for compound $\mathbf{5 b}$ with a chloro moiety attached to the pyrimidine ring at the 4-position. Its $\mathrm{LC}_{50}$ value $(0.22 \%)$ towards Culexpipiens is very significant. Other chloro compounds $\mathbf{4}$ and $\mathbf{5 a}$ showed also an appreciable toxicity. Their $\mathrm{LC}_{50}$ values $(0.43$ and $0.61 \%)$ are very interesting. On the other hand, deformation of the treated larvae was observed by effect of different compounds due to molting inhibition for the next stages. The treatment of $C$. pipiens larvae with different compounds of condensed pyrimidine resulted in a significant inhibition of adult emergence of $C$. pipiens. In light of the results presented in this work and taking into account that this preliminary study does not produce conclusive evidence regarding a structure-activity relationship, we have focused our attention on the most promising compound $\mathbf{5 b}$ as an interesting starting point for the development of a new class of chemical insecticides. Further structural modifications might lead to the discovery of more potent insecticides and this work is in progress. We believe that research in this direction should be encouraged in order to broaden the applicability of these new heterocyclic frameworks to serve as leads for designing novel chemical insecticides.

\section{References:-}

1. Agarwal, N., P. Srivastava, S. K. Raghuwanshi, D. N. Upadhyay, S. Sinha, P. K. Shukla, and V. J. Ram. 2002. Chloropyrimidines as a new class of antimicrobial agents. Bioorg. Med.Chem. 10:869-874.

2. Borisenko, V. E.; Krekov, S. A.; Fomenko, M. Y.; Koll, A., Lipkovski; 2008.Struct., No-carrier-added (NCA) aryl (18E) fluorides via the nucleophilic aromatic substitution of electron rich aromatic rings. P. J. Mol. 882, 923.

3. Balalaie, S.; Bararjanian, M.; Rominger, F. J. Heterocycl. Chem. 2006, An efficient one-pot synthesis of 6-aryl5-cyano-2-thiopyrimidinone derivatives and their piperidinium ionic forms, x J. Heterocycl. Chem. 43, 821826.

4. Pomeisl, K.; Holy, A.; Votruba, I. 2008. Pyrimidine acyclic nucleoside phosphonates and phosphorylated analogs. Part 2. Syntheses and investigation of their inhibitory effects towards human thymidinphosphorylase, J. Nucleic Acids Symp. Ser.(Pubmed) 657-658.

5. Zhu KY, Heise S, Zhang JZ, Anderson TD, Starkey SR. 2007; Comparative studies on effects of three chitin synthesis inhibitors on common malaria mosquito (Diptera: Culicidae) Journal of Medical Entomology. 2007;44:1047-1053. 
6. M Belen Cassera, Y Zhang, K Z Hazleton, V L Schramm, 2011. Purine and pyrimidine pathways as targets in Plasmodium falciparum, Current topics in medicinal chemistry 11 (16), 2103-2115.

7. Rehimi, N., 2004. Etude de la reproduction chez Culexpipienspipiens. Aspects: morphologique, éthologique et physiologique. Effets de quelquesinhibiteurs du développementsurquelquesparamètresbiologiques. Thèse de doctorat d'état en Sciences Naturelles, mention BiologieAnimale. Universitéd'Annaba, Algérie. 195 p.

8. Rehimi, N., Soltani, N., 1999. Laboratory evaluation of Alsystin, a chitin synthesis inhibitor, against Culexpipiens (Dip., Culicidae): effects on development and cuticle secretion. Journal of Applied Entomology 123, 437-441.

9. Bahara . c, Chiara . b, Giampiero. s, Karl-Norbet, Magdalena. B, Fransca . D, stefono . M activity profile. J . purineergicsignalling . 2007, 3 (3), $183-193$.

10. wiley- liss, Inc. wapertal . A .G. Germany website PMD . Drug Dev . Res . 2001, 406 - 415.

11. Gaber, H. M.; Bagley, M. C.2009, Unlocking the chemotherapeutic potential of beta-aminovinyl ketones and related compounds. Chem Med Chem .4, (7), 1043-1050.

12. Hatem M. Gaber, Mark C. Bagley, Sherif M. Sherif, and Usama M. Abdul-Raouf, J.

13. 13. Heterocyclic Chem., 2010,to novel tricyclic and Promising antimicrobial agents: Synthetic approaches tetracyclic pyrimidinones with antimicrobial properties, J. Heterocyclic Chem.V.47 (5), 1162-1170.

14. Hatem M. Gaber, Mark C. Bagley, Sherif M. Sherif and Mohsen A. Sayed, Z.Naturforsch., 201 Promising antimicrobial agents: Synthetic approaches to novel tricyclic and tetracyclic pyrimidinones with antimicrobial properties. J. of Heterocyclic chemistr,66b, 585-596.

15. REHIMI N. \& SOLTANI N. 2002. Laboratory evaluation of andalin, a new insecticide interfering with cuticle deposition, against Culexpipiens. Revue Sciences \&Technologie, 18: 106-110.

16. Anonyme, WHO/VBC/83. 1983 , PP. 883.

17. Abbott, W. S. (1925): A method of computing the effectiveness of an insecticide. J. Econ. Entomol., 18: 265267.

18. Finny, D. J. 1971. ProbitsAnalyse (3rd ed.), Campridje University Press, London.

19. Abu-Shanab, F. A.; Elkholy, Y. M.; Elnagdi, M. H. Synth. Commun. 2002, Enaminones as building blocks in organic synthesis: synthesis of new polyfunctional pyridines, condensed pyridines, and penta substituted benzene, Synth. Communications,.32 (22), 3493-3502.

20. Vicini, P.; Geronikaki, A.; Anastasia, K.; Incerti, M.; Zani, F. 2006, Synthesis and antimicrobial $\quad$ activity of novel 2-thiazolylimino-5-arylidene-4-thiazolidinones.J. Bioorg. Med.Chem 14, 3859- 3864.

21. Cho, N. S.; Shon, H. I.; Parkanyi, C.1991, Synthesis and properties of 5-aroylamino-2H-1,2,4 thiadiazol-3-ones. J. Heterocyclic Chem. 28, 1725-1729.

22. Robba, M.; Touzot, P.; El-Kashef, H., Series: Advances in Heterocyclic Chemistry, J. Heterocyclic Chem. 1980, 17, 923-928;

23. Robba, M.; Touzot, P.; Riquelme, R. M. 1972, Synthese de benzo (1) thieno [2,3-d] pyrimidines et de benzo (1) thieno [3,2-d] pyrimidines. Tetrahedron Lett. (44), 4549-4551;

24. Robba, M.; Touzot, P.; Riquelme, R. M. C. R. Acad. Sci. (c) 1973, 276,93- 95.

25. Girgis, N. S.; Jørgensen, A.; Pedersen, E. B.1985, Synthesis, Phosphorus Pentoxide in Organic Synthesis; XI ${ }^{1}$. A New Synthetic Approach to 7-Deazahypoxanthines, (1),101-104.

26. Perrissin M, Favre M, Luu-Duc C, Bakri-Logeais F, Huguet F, Narcisse G. 1984. [Thieno[2,3-d]pyrimidones: synthesis, structure and pharmacological properties]. Eur J Med Chem.; 19: 420424.

27. Shvedov, V. I.; Ryzhkova, V. K.; Grinev, A. N. Khim. Geterotsikl. Soedin. 1967, (in Russian); $\quad$ Chem. Heterocycl. Compds. (Engl. Transl.), 3, 3(3), 459-460.

28. Edrees, M. M.; Farghaly, T. A.; El-Hag, F. A. A.; Abdalla, M. M. Eur. 2010. Antimicrobial, antitumor and 5 $\alpha-$ reductase inhibitor activities of some hydrazonoyl substituted pyrimidinonesJ. European journal of medicinal chemistry 45 (12), 5702-5707.

29. Shawali, A. S.; Abbas, I. M.; Mahran, A. M. J. Iranian Chem. Soc. 2004, 1(1),33-39.

30. Griffin, R. J.; Srinivasan, S.; Bowman, K.; Calvert, A. H.; Curtin, N. J.; Newell, D.

31. R.; Pemberton, L. C.; Golding, B. T. J. Med. Chem. 1998, 41(26), 5247-5256.

32. Tornetta, B.; Siracusa, M. A.; Ronsisvalle, G.; Guerrera, F. Gazz. Chim. Ital. 1978, 108, 57-62.

33. Sauter F.2011. Chemistry of sulfur-containing heterocycles. I. Synthesis of benzo[b]thieno[2,3-d]pyrimidine derivatives. Monatsh Chem., 99: 1507-1514. doi:10.1007/BF00902701.

34. Alegaon, S. G.; Alagawadi, K. R. Eur. J. Chem. 2011, 2(1), 94-99. 
35. SAG Abdel-Aziz, TES Ali, KM El-Mahdy, SM Abdel-Karim ,2011.Synthesis and antimicrobial activities of some novel bis-pyrazole derivatives containing a hydrophosphoryl agent, unit European. Journal of Chemistry 2 (1), 25-35.

36. Tsuji, K.; Nakamura, K.; Ogino, T.; Konishi, N.; Tojo, T.; Ochi, T.; Seki, N.;

37. Matsuo, M. Chem. Pharm. Bull. 1998,Studies on anti-inflamatory 46(2), 279-286.

38. Brehme, R., Grundemann, E., Schneider, M., Radeglia, R., Reck, G., \& Schulz, B. (2003). Aza-enamines X: Formylation of pyrazole-4-carbaldehyde hydrazones at the hydrazonoazomethine C-atom .SynthesisStuttgart, (10), 1615-1619.

39. Nandeeshaiah, S. K.; Ambekar S. Y. 1994, SYNTHESIS OF 2-ARYL-1,2,3,4-TETRA HYDROPYRIDO[2',3' 4,5]THIENO[2,3-B]QUINOLIN-4-ONES/ .Indian J. Chem. 33B, 375-379.

40. El-Desoky, E.-S. I.; Al-Shihry, S. S. J. Heterocyclic Chem. 2008, 45, 1855-1864.

41. Santilli, A. A.; Kim, D. H.; Wanser, S. V. J. 1971, Synthesis and biological activityofpyrido[3',2':4,5]furo[3,2d]pyrimidine derivatives as novel and potent phosphodiesterase type 4 inhibitors. J. Heterocyclic Chem, 8, 445453.

42. Abdallah, M.A. 2001. Convenient synthesis of 6H-[1,2,4,5]tetrazino[3,2-b]quinazolin-6 ones. Monatsh. Chem., 132, 959-965.

43. Badawy, M.A.; Abdel-Hady, S.A.; Ibrahim, Y.A. 1990. Synthesis and structure of some

44. thia-zole derivatives. Liebigs Ann. Chem., 393-395.

45. Shishoo, C.J.; Shirsath, V.S.; Rathod, I.S.; Brahmbhatt, S.B.; Pathak, U.S.; Jain, K.S. $1997 . \quad$ Synthesis and QSAR of some 3-amino-2-(substituted)aminomethyl-5,6-disubstituted thieno[2,3-d]pyrimidin-4(3H)-ones as novel H1-receptor antagonists. Drug Des. Discov-ery, 15, 105-115.

46. Urleb, U.; Stanovnik, B.; Tišler, M. 1990, The synthesis and transformations of 2-ethoxycarbonyl- 3isothiocyanatopyridine. Pyrido[3,2-d]pyrimidines and someazolopyrido[3,2-d]pyrimidines. J. Heterocyclic Chem., 27, 407-412.

47. El-Sherief, H. A. H.; El-Naggar, G. M.; Hozien, Z. A.; El-Sawaisi, S. M. J. 2008.

48. J.Heterocyclic Chem. 45, 467-473.

49. Oganisyan, A. Sh.; Noravyan, A. S.; Grigoryan, M. Zh., 2004,Condensed Pyridopyrimidines. 7. Synthesis of Condensed Triazolo[4,3-c]- and Tetrazolo[1,5-c]pyrimidines, J. Chem. Heterocycl. Compds. 40, 75-78.

50. Vieweg, H.; Leistner, S.; Prantz, J.; Bohm, N.; Wanger, G. Pharmazie 1992, [Synthesis of N-(2- carboxythieno(2,3-b)pyridin-3-yl)-amidines by the reaction with 4-oxo-4H-pyrido(3',2':4,5)- thieno(3,2-d)-1,3-oxazines with secondary cycloaliphatic amines].J. Pharmazie, 47, 841-845.

51. Shaban, M. E.; Youssef, A. M.; El-Aasar, N. K.; El-Ziaty, A. K. Pak. 2008. Synthesis and Reactions of Some New Substituted Benzoxazin-4-One and Quinazolin-4-One J. Sci. Ind. Res., 51(3), 119-123.

52. Stanczak, A.; Pakulska, W.; Pietrzak, B.; Lewgowd, W. 2001. Comparison of pharmacophorecinnoline and quinoline systems on the basis of computer calculation and pharmacological screening of their condensed systems, Pharmazie (Berlin),56, 501-505.

53. Briel, D.; Rybak, A.; Kronbach, C.; Unverferth, K.; Tanarro, C. M. G.; Gutschow, M.2008, J. Heterocyclic Chem., 47, 634-639.

54. Alouani A, Rehimi N, Soltani N, (2009). Larvicidal Activity of a Neem Tree Extract (Azadirachtin) Against Mosquito Larvae in the Republic of Algeria,, Jordan J Biological Sci., 2(1): 15-22.

55. Del Guercio. (1900). NuoveRelazioniIntornoaiLavoridella R. Stazione di EntomologiaAgraria di Firenze Serie Prima 2:114, 116 >> Cerosipha :Aphid.speciesfile.org:TaxonName:10990 